TEME, г. XLV, бр. 1, јануар - март 2021, стр. 179-192

Прегледни рад https://doi.org/10.22190/TEME200207092K

Примљено: 7. 2. 2020.

Ревидирана верзија: 6. 2. 2021.

Одобрено за штампу: 26. 2. 2021.

\title{
A DOCTRINAL JUSTIFICATION OF THE INSTITUTION OF COMPULSORY SHARE IN MODERN LEGISLATURE
}

\author{
Novak Krstić*
}

University of Niš, Faculty of Law, Niš, Serbia

\begin{abstract}
In terms of content, compulsory share is the most efficient and effective testation restriction. In the European Continental legal systems, this institution allows a testator's family members to inherit a legally defined portion of the inheritance against the testator's will. In modern legal theory and practice, the question is increasingly raised regarding the justifiability of guaranteeing the compulsory share. Views advocating a comprehensive restriction, even an outright abolition, of this institution are gaining prominence, arguing as they are for each individual to thus be able to fully exercise their property rights as they see fit. Although this has been the subject of fierce debate in legal circles recently, one must bear in mind that the compulsory share is a very important inheritance law institution with multiple functions, and that it should not be called into question in Europe. Therefore, the present author outlines the classical theories justifying the existence of the institution of compulsory share, analyses their basic tenets and ideas, and goes on to put forward his observations regarding which arguments can be used to defend regulating compulsory inheritance in modern legal systems.
\end{abstract}

Key words: compulsory share, testator, will, theories of compulsory share justifiability.

\section{ДОКТРИНАРНО ОПРАВДАЊЕ ПОСТОЈАЊА УСТАНОВЕ НУЖНОГ ДЕЛА У САВРЕМЕНОЈ ЛЕГИСЛАТУРИ}

\section{Апстракт}

Нужни део је садржински најефикасније и најделотворније ограничење слободе завештајног располагања. Овом установом у правима европско-континенталног правног круга обезбеђује се најближим члановима оставиочеве породице да и супротно његовој вољи наследе законом дефинисани део заоставштине. У савременој правној теорији и пракси све се чешће поставља питање оправданости гарантовања права на нужни део. Све су гласнији ставови за потребом свеобухватне рестрикције,

\footnotetext{
* Аутор за кореспонденцију: Новак Крстић, Универзитет у Нишу, Правни факултет,
} Трг краља Александра 11, 18105 Ниш, Србија, novakkrstic@yahoo.com 
чак и његовим потпуним укидањем, како би се сваком појединцу омогућило да последњом изјавом воље располаже својим имовинским правима у потпуности према сопственом нахођењу. Премда се последњих година о овоме воде жестоке расправе у правничким круговима, мора се имати у виду да је нужни део веома значајан институт наследног права, чија је функција вишеструка, те да не треба доводити у питање његово егзистирање на европском континенту. У том смислу, аутор у раду указује на класичне теорије којима се оправдава постојање установе нужног дела, анализира њихове основне поставке и идеје, а потом износи и своја запажања о томе којим се аргументима данас може бранити регулисање нужног наслеђивања у савременим законодавствима..

Кључне речи: нужни део, оставилац, завештање, теорије о оправдању нужног дела.

\section{INTRODUCTORY REMARKS}

Freedom of testation is one of the basic principles of succession law and the first principle of inheritance by will (Langbein, 1975, p. 491). Setting limits to the freedom of testation is one of the central questions of modern law of succession and the focus of codifiers in developing largescale codifications. The freedom of testation is an expression of the autonomy of will and a consequence of the view that only the bearer of property rights, competent to make a will, is authorized to dispose of said rights through a unilateral legal act of mortis causa as he/she sees fit. Traditionally, the freedom of testation is understood as an assumption of the property right with important functions, such as reinforcing parental authority, maintaining sound relationships amongst the children and the family in general, in order to avoid the breaking up or disintegration of the family (Parra, 2009, 497). This freedom contributes to a greater need for producing and saving more wealth (Hirsch, 2011, p. 2187), as well as further investments and increased productivity (Kelly, 2013, p. 1127), so that the property gained would be left to the desired beneficiaries in a last will, and is therefore an instrument ensuring the maintenance and growth of family wealth. It also affects familial relationships by enabling parental control over children and encouraging children to care for their parents (Kelly, 2013, pp. 1127-1128), in order not to be disinherited.

Nonetheless, the freedom of the testator to leave his/her property to the persons he/she sees as the fittest, most valuable, or simply dearest, has never been unrestricted. The need of the society to protect in some degree the property interests of the persons closest to the testator goes beyond the interest of ensuring the full freedom of testation (Antić, 1983, p. 19) and represents "the exact opposite of the full freedom of testation" (Marković, 1955, p. 113). The compulsory share is a portion of inheritance, expressed in value terms, which must be transferred to the legally defined group of the testator's family members, if they so request. The institution of compulsory share originates from the ancient Roman law at the time of the Republic, and is recog- 
nized by all the legal systems which continue the tradition of the European Continental law and are part of its family; these legal systems regulate the institution of compulsory share via the rules of cogent legal nature, and therefore their legal effect cannot be annulled by the testator's will.

The compulsory share has always occupied the space at the boundary between the freedom of testation and the principle of family inheritance. From a theoretical viewpoint, this institution simultaneously realizes the constitutionally guaranteed succession right and provides family protection (Kipp, Coing, 1990, p. 51). Still, just like the very institution of succession, the institution of compulsory share has always been subjected to numerous critical assessments, but in a comparatively greater degree. Calls to abolish, or at least modify, the institution of compulsory share have been more and more frequent in the area of the succession right theory, giving the individual more freedom to dispose of his/her property rights (more: Cámara Lapuente, 2011, pp. 283-289). It is pointed out that it runs contrary to the freedom of the individual to autonomously dispose of the assets in his/her possession; that the duty of supporting children expires after a certain number of years; that it should not be permanent; as well as that the assets gained belong to a single person and not the entire family, and that therefore they do not have to be transferred to the family members after the death of the owner (Lamarca i Marquès, 2014, p. 267). It is often said that guaranteeing the absolute freedom of testation encourages people to work, produce and acquire more assets, as they know that they have an unrestricted possibility of leaving them to persons of their own choosing (Hirsch, 2011, p. 2187). In German theory, opponents of this institution underline the danger to the operation of big companies due to the distribution of property among inheritors. Specifically, the compulsory share jeopardizes companies because when it is paid out in money, the debtor often has to sell a part of the company in order to cover the value of the compulsory share (Schöpflin, 2006, pp. 5, 8). It is for these reasons that in many European legal systems a trend can be identified of narrowing down the number of compulsory inheritors, setting the compulsory share in money, as well as broadening the reasons for the exclusion of compulsory inheritors (Pintens, 2003, p. 423). Italy has seen the initiative to abolish the compulsory share, ${ }^{1}$ and there are views among European legal experts that the work on unifying European civil law will be geared towards its abolition (Sonnekus, 2005, pp. 83-84).

\footnotetext{
${ }^{1}$ See the document: Disegno di legge No. 576, dated 16 May 2008, available on the following link: http://www.senato.it/leg/17/BGT/Schede/Ddliter/40632.htm. The Italian parliament did not take this matter under consideration, and the doctrine deemed it very radical, pointing out that protecting the freedom of testation does not require a full derogation of compulsory inheritance (Dossetti, 2009, p. 35).
} 
Today, when the institution of compulsory share is subjected to harsh criticism and contested to the point of calling into question its very existence in some legal systems, it is necessary to consider afresh the question of whether this institution deserves the place it has in modern legal systems and what its future holds. Therefore, this paper will point out the most important theoretical perspectives justifying the existence of the institution of compulsory share and outline a specific view on the status of this institution de lege ferenda, as well as on possible approaches to modifying it.

\section{THE LEGAL AND PHILOSOPHICAL VIEWS ON THE JUSTIFICATION OF THE INSTITUTION OF COMPULSORY SHARE}

As the institution of compulsory share has always been criticised and contested, it was necessary to formulate a valid justification for its existence in modern legal systems, which place more and more emphasis on the freedom of the individual and develop the concept of individualism and liberalization. Various theories have been put forward, based on diverse philosophical approaches, attempting to identify the foundations of the compulsory share. Some of the most important ones are discussed below.

\section{The Tacit Fideicommissum Theory}

Fideicommissum is an institution originating from the ancient Roman law and is related to the legal acts of mortis causa. Initially, it was a moral institution and not a legal one, but it was subsequently articulated legally for practical reasons (Vujović, 2018, p. 87). Via fideicommissum quod familiae relinquitur, the testator tried to ensure that a family house remained within the family and to prohibit its alienation. Hence, fideicommissum is often characterized as an estate that becomes inalienable for all future generations as per the will of its owner, and which must be transferred to family members. $^{2}$

The tacit fideicommissum theory gives special emphasis to the family dimension of inheritance. According to this doctrinal viewpoint, the compulsory share is seen as an expression of the need to keep at least a portion of the ancestors' property within the family for future generations. Each person is obliged to ensure the welfare of his or her descendants.

Each individual is one of the stones in the family foundation - tied to a long line of ancestors, with possible ties to an indefinite number of descendants. "He is but a link in a chain whose beginning is no longer known and

\footnotetext{
${ }^{2}$ But, fideicommissum did not have an absolute effect. It only constrained the family members indicated in the will, and not other relatives, so the generations that followed could alienate said property (Hillner, 2003, p. 134).
} 
whose end may never be known" (Pantelić, 1937, p. 348). The goods that he/she possesses are a result of work, accumulation and saving on the part of known and unknown ancestors, who contributed shares - impossible to determine - to the family wealth (Lair, 1865, pp. 212-213). It is in this sense that the current holder of an economic good is only its keeper, and has no right to break the chain of inheritance or to alienate the good of his/her own accord by testation, as in this way he/she would go against the will of the ancestors. Even when wealth is not a consequence of economic accumulation over generations, and instead only of the work of its owner, the proponents of this theory stand by their view, claiming that this very individual result comes from the ability passed on from ancestors and from education acquired within the family (Lair, 1865, p. 213).

The tacit fideicommissum theory has many shortcomings. One shortcoming that is often pointed out is that the basis for the compulsory share is found in a legal phenomenon which, historically speaking, did not play a big role in everyday legal activities, except in the period of feudalism (Antić, 1983, p. 235), while most of modern legal systems prohibit or restrict it. Another major shortcoming lies in the fact that in fideicommissum the restriction of testation relates only to inherited property, which as a rule is a specific immovable asset, and not non-inherited property. There is no such separation in the compulsory share.

\section{The Family Property Theory}

As a philosophical view providing a justification for the compulsory share, the family property theory in some sense builds upon the assumptions of the tacit fideicommissum theory. In this theoretical standpoint, the justification for the legal prescription of retaining a portion of inheritance in the family is found in the family (co-)property as a form of property which preceded individual, private property across all societies.

The origin of the institution of compulsory share is found in family property, which ensures that a portion of inheritance remains within the family. The advocates of this view point out that, historically speaking, in the past family assets could not be alienated without the permission of other family members, as property is not a consequence of labour and production of a single person but an entire generational chain, and that therefore each individual owes his/her existence and welfare to the entire family (Antić, 1983, p. 236). The proponents of this approach find additional arguments in the principles of family ethics: by the very nature of things, it is necessary for the family property to remain available to family members in order, among other things, to provide for each of its members. At the same time, it is pointed out that children are their parents' natural heirs and that a system should be established which would ensure equality among children as well as prevent parents from unjustly discriminating against them, which may result in family squabbles, disagreements, and envy (Parra, 2009, p. 497). 
The family property theory is based on an institution that has long since disappeared from modern law. It is therefore very difficult to justify the positive legal norms of the compulsory share by an institution that held sway in ancient legal systems. When individual property replaced collective property, disposal of assets is no longer subject to such restrictions. This is why this doctrinal view cannot justify the existence of the compulsory share today.

\section{The Support (Alimony) Theory}

Family law prescribes the persons which the legal obligation of support relates to, as well as the conditions for providing support (Batbie, 1866, p. 103). Further, the provisions regulating the obligation of ancestors to provide support for their descendants (above all the obligation of parents to provide support for their children), as well as the obligation of descendants to provide support for their ancestors, are especially important. The legal obligation of support stops with the death of the support provider and is not transferred to his/her heirs. According to the views of the alimony theory advocates, the compulsory share aims to ensure and continue support from the inherited property for the persons that a testator had the obligation to support in his/her lifetime. Its purpose is to ensure a continued existence of the obligation of support after the debtor's death, which corresponds to the natural obligation existing and linking ancestors and descendants and vice versa.

This theory has the greatest number of proponents in the domestic legal doctrine. After the Second World War, at a time when rules for compulsory inheritance were articulated, legal experts pointed out that the compulsory share no longer serves to maintain family property but rather to provide support for junior descendants and incapacitated persons (Konstantinović, 1947, p. 339); they also pointed out that the justification for the compulsory share lies in the duty of support and care that the testator had or could have had while alive (Blagojević, 1969, pp. 180-181). The compulsory share prevents the testator from freely disposing of his/her property rights of mortis causa to the detriment of the persons he/she is obligated to support and provide material assistance to while alive (Šinkovec, \& Tratar, 2005, 108). Younger legal writers take the view that, although it is difficult to find a single basis for the compulsory share for all times and territories, the alimony theory, with its advance for future support, is still the most realistic justification for the compulsory share (Stojanović, 2011, p. 142), if modified in a manner that avoids the shortcomings of a pure alimony theory. The modification refers to the compulsory share being provided in money and not in natura, with exceptions stemming from the rights of inheritors who lived or worked in a community with the testator (Antić, 2009, p. 191).

In foreign legal theory, however, the support theory has few proponents. The shortcomings of this theory regarding the justification for 
the compulsory share are being increasingly pointed out. Its premises are said to be antiquated, as the living conditions are different now than they were in the past, and children are no longer as dependent on their parents as before (Csehi, 2011, p. 179). It is also said that children often contribute to the growth of family property, and that even if they do not work, they certainly can contribute, so that parent-child transfers go both ways (Lamarca i Marquès, 2014, p. 274). The alimony theory cannot explain why the group of compulsory inheritors does not match the group of persons with the right of legal support recognized by legal systems. In addition, many compulsory inheritors' right to the compulsory share is recognized even though they are financially secure and do not need to be supported. Lastly, unlike support, the compulsory share is not paid out in instalments, nor is it sufficient to meet the basic needs of a compulsory inheritor; rather, it is paid in a set one-off sum or in the form of a legally prescribed share in inherited property.

\section{The Family Solidarity Theory}

The family solidarity theory has many proponents in both foreign and domestic legal doctrines. The spiritual and material solidarity among family members as one of the basic family links has survived the disappearance of family property and is the likely reason for the society's insistence upon providing family members with a portion of the inheritance despite the testator's will. Intergenerational solidarity is traditionally seen by foreign legal writers as the foundation of the institution of compulsory share (Lamarca $\mathrm{i}$ Marquès, 2014, pp. 273-274; Pintens, 2011, p. 12). It implies that individual inheritors must not be sidestepped in the distribution of inheritance. This results from the fact that no one is born alone and dies alone, and that generational continuity ought also to be seen in terms of the compulsory share (Lamarca i Marquès, 2014, p. 274). It is pointed out that family solidarity should exist not only while a family member is alive but also after their death. ${ }^{3}$

The basic function of the compulsory share is to provide support, but it is observed that nowadays children often inherit at a point when they are already financially secure, so that the compulsory share is no

${ }^{3}$ Considering the nature of the right of children to the compulsory share, the German Constitutional Court passed the decision on 19 April 2005 to the effect that the right of children to the compulsory share is a constitutionally guaranteed right based upon universal solidarity among family members - a psychological as much as an economic link. Therefore, the function of the compulsory share is to maintain the psychological and economic unity of the family, independently of the economic needs of the testator's children (BverfG NJW 2005, 1561 - BVerfG v. 19.4.2005 - 1 BvR 1644/00 und 1 BvR 188/03). The decision is available on the following link: http://lorenz.userweb.mwn.de/ urteile/1bvr1644_00.htm. 
longer a means to provide financial security, but rather to improve the living standard. Therefore, the function of the compulsory share is no longer understood as extending the obligation of parents to support their children. Parents end their duty by providing their children with the opportunities for education (Pintens, 2011, pp. 12-13).

Alongside the importance of the alimony theory, the domestic legal scholarship underscores the role of family solidarity as a foundation of the institution of compulsory share, in particular as it must be provided forthwith, without any restrictions. If in his/her mortis causa disposals the testator sidesteps his/her family members, such disposals are legally ineffective (Marković, 1981, p. 184). Analysing the postulates of the other philosophical views justifying the compulsory share, Pantelić identifies family solidarity in each one of them. He defines it as the "unconscious and conscious interdependence of family members and their linked interests, connecting them in time and in space" (Pantelić, 1937, p. 347). He sees the compulsory share as a social sanction of mutual rights and duties of the testator and the persons closest to him/her, primarily the duties of the testator towards his/her closest family, stemming from family solidarity (Pantelić, 1937, p. 348).

Solidarity among family members strengthens the family's economic aspects as well, and family certainly is an important economic factor in the society. Family members contribute to the production of material and nonmaterial goods. The cooperation between family members increases the wealth of the family as well as that of each individual. This is why after the death of a family member the closest relatives should participate in the distribution of property that the family member had accumulated (Schöpflin, 2006, p. 9). As it ensures that many family members obtain a portion of the testator's property, the right to the compulsory share stimulates economic cooperation within the family as well as interpersonal cooperation.

The family solidarity theory has its shortcomings as well. The biggest one lies in the fact that one legal institution is justified by means of a higher, non-legal concept, whose content is difficult to define. The reasons for the existence and survival of a legal institution, it is claimed, should be sought in the legal domain, among other legal institutions (Antić, 1983, p. 241). In addition, what is also questionable is the quantum of solidarity among today's family members, with whom the egotistical, property-related interests prevail, often destroying the substrate of this concept.

\section{The Theory of the Threefold Basis of the Compulsory Share}

As all of the views above are one-sided and for the most part interpret from one vantage point such a complex institution as the compulsory share, Gustave Boissanade formulated the so-called theory of the threefold basis of the compulsory share. He tried to locate the basis of the compulsory share in the symbiosis of the theory of tacit fideicommissum, alimony and family property, indicating the advantages of these theories and combining their 
basic principles, which have already been discussed in the present paper (more: Boissonade, 1873, pp. 539-545).

The ideas behind the theory of the threefold legal basis providing justification for the institution of the compulsory share are not acceptable. This view suffers from the entire gamut of the shortcomings of each of the theories that it is based upon.

\section{ON THE IMPORTANCE OF THE INSTITUTION OF COMPULSORY SHARE TODAY AND THE REASONS FOR ITS NORMATIVE EXISTENCE DE LEGE FERENDA}

Succession law is conservative in character and burdened with tradition (Vaquer Aloy, 2011, p. 91), and the institution of compulsory share has for centuries been deeply rooted in the rights belonging to the European Continental family of law. In accordance with the social notion of justice, it is disallowed in the European legal culture for the testator's closest family to be left without a single portion of the inheritance (Kipp \& Coing, 1990, pp. 51-53).

The manner in which each state regulates it is conditioned by numerous social determinants: the historical moment that a society is in, its social and cultural specificities (Foqué \& Verbeke, 2009, p. 204), the political, legal, philosophical, sociological, and ethical views on the importance of family, familial relations and values, the role of the individual in the society and his/her freedoms, etc. Therefore, the legislation surrounding compulsory inheritance reflects the legal and political ideas of the legislator pertaining to highly complex issues from various social and legal domains. The legal provisions governing the institution of compulsory share are designed in such a way as to reconcile two opposed requirements: 1 . To limit the freedom of testation, more broadly the free disposals on the part of the testator which might impair the material position of the persons closest to him/her - the compulsory inheritors, which is the primary goal; and 2 . To ensure that the limitations are devised in such a way as for the freedom of testation and all other unencumbered disposals not to be overly narrow, as well as for the legal security of the beneficiaries of charitable legal transactions not to be impaired (Krstić, 2012, p. 442).

All of the above indicates that the institution of compulsory share has a future. The provisions regarding the group of compulsory inheritors and the manner in which the compulsory share is implemented may vary between states; legal reforms may narrow down the group of persons whose right to the compulsory share is recognized, or the size of the compulsory share; they may prescribe additional conditions for the exercise of this right, and find new ways of expanding the freedom of testa- 
tion. ${ }^{4}$ However, calling into question the existence of this institution, and even thoroughly redefining the basis it has had for centuries, does not appear realistic. ${ }^{5}$ Individual attempts of some theorists and practitioners cannot shake the foundations of this institution in the European legal systems. The arguments justifying the regulation of compulsory inheritance are sufficiently solid not to jeopardize its existence.

The full complexity of this institution is reflected, among other things, in the theoretical postulates and philosophical views discussed above, which locate the reason for the existence of the institution of compulsory share in the variegated legal and non-legal institutions and concepts. Still, the starting assumptions of all these theories are questionable, and many objections to them are raised in legal doctrines, pointing out their shortcomings.

In light of the above, it can be concluded that no philosophical view explains in full the ratio of an institution as complex as the compulsory share. What all of these theories have in common, which is an advantage that they have, is that they address the family law component of the institution of compulsory share. Family is the basis of society, not the individual, and goods are produced within the family, so that the compulsory share is an expression of co-existence within the family, which is based not only on give-and-take, but rather represents the totality of the complex relations between its members. The familial character of inheritance is the reason why close family are provided with more than the right to support, and this is why after the death of a family member a portion of the inheritance should go to family members.

\footnotetext{
${ }^{4}$ One of the basic characteristics of the compulsory share is that it is fixed for each compulsory inheritor in advance (Marković, 1981, p. 185; Foqué \& Verbeke, 2009, p. 210), which leaves no room for adapting the size of the compulsory share to the circumstances, e.g. the needs of the compulsory inheritors or their contribution to the growth of the inheritance value. This is why it may be considered unjustified for someone who is financially secure and who has not contributed to the growth of the inheritance to receive a portion of it independently of the testator's will, and even directly against it. Ideas have been put forward for reforms of compulsory inheritance which would ensure that the size of the compulsory share is not preset; rather, the court would decide for each individual case based on the needs of the closest family members (Delgado Echeverría, 2006, p. 128). For this reason, some legal systems allow the testator to reduce the compulsory share of the inheritors that have become alienated from him/her over the course of their lifetime (more: Foque \& Verbeke, 2009, p. 214). This contributes to the flexibility of this institution, as against its per definionem rigidity.

${ }^{5}$ Due to the fact that an increasing number of states only recognize the right of the compulsory inheritors to request the monetary value of the compulsory share, as they are disallowed from participating in the distribution of the inheritance in natura, some authors are of the opinion that the compulsory share persists, but in a modified and weakened form (Vaquer Aloy, 2011, p. 93). As paying the value of the compulsory share may be a great burden for the debtor, some legal systems envisage the possibility of deferred payment or payment in instalments of the value of the compulsory share (more: Softić Kadenić, 2011, pp. 37-38).
} 
Therefore, the compulsory share is in a sense an instrument through which the state intervenes among family members in order for the family to be able to fulfil its basic social functions. It prevents an excessive removal of property from the bounds of the persons closest to the testator, thus providing for these persons, and a more equitable distribution of property is ensured among those that have often, in their many different activities, brought a part of themselves to the property accumulated by the testator over the course of his/her lifetime (although this may not be the case). This institution protects the property interests of the individuals related to the testator through blood, adoptive, or partnership ties, whose effect in terms of the succession laws is recognized by legal systems.

The legislator which sets the limits to the freedom of charitable disposals assesses the degree of protection. The set limits are to an extent arbitrary, but they should be an expression of the dominant social views on the importance of facts relevant to the articulation of the rules of compulsory inheritance; they should reflect life, and not find their justification solely in a doctrinal view or a theoretical construct. Legal solutions can be based on certain theoretical postulates or philosophical ideas, but they should not be the legislator's only defence line, or an excuse for defending the designed legal solution. Although the institution of compulsory share bears the marks of conservatism and relative duration that does not imply that it is immutable. Law is a living thing, it follows the metamorphosis of the society and adapts to specific flows of life, which it then shapes in a socially acceptable way. The same goes for the norms of compulsory inheritance, which ought to be an expression of current social views on the importance of family values and should reflect them faithfully.

\section{CONCLUSION}

In the author's opinion, the basis for a legal institution need not be found in legal concepts, institutions or rules. Numerous legal institutions have arisen precisely as an expression of philosophical views on certain social phenomena and the need for their shaping by legal norms.

The postulates of the alimony theory can be a starting point for explaining the existence of the compulsory share, but in and of itself it is not sufficient for justifying this institution. The compulsory share often does not depend on the needs of compulsory inheritors; rather, they are guaranteed the compulsory share irrespective of their personal assets; furthermore, parents invest significant resources over the course of their lifetimes in schooling, education, and general well-being of their children. Even today, when the links between family members are weakening, when alienation is indisputable, and a sense of belonging to the family dissipating, when the general material situation is better and the opportunities for able-bodied family members to make a profit greater, family solidarity remains a value in its own right. 
Therefore, the rules of compulsory inheritance should be formulated based on family solidarity, with the aim of providing existential security to the persons closest to the testator; above all, however they must be built on the foundations of the dominant modern understanding of which persons are to be considered especially close to the testator - so close that it would be justified to restrict the freedom of testation in the interests of these persons. The author believes that the combination of the above is where the ratio legis of the compulsory share should be sought.

\section{REFERENCES}

Antić, O. (2009). Nasledno pravo [Succession Law]. Beograd, Službeni glasnik.

Antić, O. (1983). Sloboda zaveštanja $i$ nužni deo [Freedom of Testation and Compulsory Portion] (doktorska disertacija) [PhD Dissertation]. Beograd.

Batbie, M. A. (1866). Révision du Code Napoléon. Correspondant (liv. du 25 Janvier 1866).

Blagojević, B. (1969). Nasledno pravo SFRJ [Succession Law of SFRY]. Beograd, Zavod za izdavanje udžbenika.

Boissonade, G. (1873). Histoire de la réserve héréditaire et de son influence morale et économique. Paris, Guillaumin.

Cámara Lapuente, S. (2011). Freedom of Testation, Legal Inheritance Rights and Public Order under Spanish Law. In Anderson, M., \& Arroyo i Amayuelas, E. (Eds.), The Law of Succession: Testamentary Freedom, European Perspectives (pp. 269-305). Europa Law Publishing.

Csehi, Z. (2011). The Law of Succession in Hungary. In Anderson, M., \& Arroyo i Amayuelas, E. (Eds.), The Law of Succession: Testamentary Freedom, European Perspectives (pp. 167-190). Europa Law Publishing.

Delgado Echeverría, J. (2006), Una propuesta de politica legislativa en derecho de sucesiones por causa de muerte. In Derecho de sucesiones: presente y futuro: XI [i.e. XII] Jornadas de la Asociación de Profesores de Derecho Civil, Santander, 9 a 11 de febrero de 2006 (pp.13-172).

Dossetti, M. (2009). Concetto e fundamento della successione necesaria. In Bonilini G. (Ed.), Tratatto di diritto delle successioni e donazioni, III, La Successione legitima (pp. 5-43). Milano.

Foqué, R., \& Verbeke, A. (2009). Conclusions - Towards an Open and Flexible Imperative Inheritance Law. In Castelein, C., Foqué, R., \& Verbeke, A. (Eds.), Imperative inheritance law in a Late-Modern Society: Five perspectives (pp. 203-221). Antwerp | Oxford | Portland.

Hillner, J. (2003). Domus, Family, and Inheritance: The Senatorial Family House in Late Antique Rome. The Journal of Roman Studies, 93, 129-145.

Hirsch, A. (2011). Freedom of Testation/Freedom of Contract. Minnesota Law Review, 95(6), 2180-2253.

Kelly, D. B. (2013). Restricting Testamentary Freedom: Ex Ante Versus Ex Post Justifications. Scholarly Works, Notre Dame Law School, 82, 1125-1185. Paper 950.

Kipp, T., \& Coing, H. (1990). Erbrecht - Ein Lehrbuch. Tübingen.

Konstantinović, M. (1947). Opšte napomene uz Teze za predprojekt Zakona o nasleđivanju [General Notes with Theses to a Pre-law of Law of Succession Act]. Arhiv za pravne $i$ društvene nauke [Archive for Legal and Social Sciences], 3, 334-347. 
Krstić, N. (2012). O priračunavanju poklona u obračunsku vrednost zaostavštine [Including Gifts in the Assessed Value of the Succession Estate]. Zbornik radova Pravnog fakulteta u Nišu [Collection of Papers Faculty of Law, Niš], $62,427-444$.

Lair, J. (1865). De la liberté de tester. Mémoire, Acad. Toulouse, 14.

Lamarca i Marquès, A. (2014). We Are Not Born Alone and We Do Not Die Alone: Protecting Intergenerational Solidarity and Refraining Cain-ism Through Forced Heirship. Oňati Socio-legal Series, 4 (2), 264-282.

Langbein, J. H. (1975). Substantial Compliance with the Wills Act. Harvard Law Review, 88, 3, 489-531.

Marković, B. (1955). Zakon o nasleđivanju - sa objašnjenjima i napomenama [Law of Succession Act - with explanations and notes]. Beograd.

Marković, S. (1981). Nasledno pravo [Succession Law]. Beograd, Službeni list SFRJ.

Pantelić, D. (1937). Osnov zakonoga dela u pravnoj filozofiji [The Ground of Compulsory Portion in Legal Philosophy]. Arhiv za pravne $i$ društvene nauke [Archive for Legal and Social Sciences], 4, 337-350.

Parra, Á. (2009). Legítimas, libertad de testar y transmisión de un patrimonio. Anuario da Facultade de Dereito da Universidade da Coruña, 13, 481-554.

Pintens, W. (2011). Need and Opportunity of Convergence in European Succession Laws. In Anderson, M., \& Arroyo i Amayuelas, E. (Eds.), The Law of Succession: Testamentary Freedom, European Perspectives (pp. 3-23). Europa Law Publishing.

Pintens, W. (2003). Europäisierung des Familien - und Erbrechts Teil II. FamRZ, 7, 417-425.

Schöpflin, M. (2006). Economic Aspects of the Right to a Compulsory Portion in the (French and German) Law of Succession. German Working Papers in Law and Economics, 34, 1-11.

Softić Kadenić, D. (2011). Novo nasljedno pravo u entitetima Bosne i Hercegovine de lege lata i de lege ferenda [New Succession Law in the Bosnia and Herzegovina Entities de lege lata and de lege ferenda]. Nova pravna revija [New Legal Review], 2(3), 36-44.

Sonnekus, J.C. (2005). The New Dutch Code on Succession as Evaluated Through the Eyes of a Hybrid Legal System. Zeitschrift für Europäisches Privatrecht, 71-87.

Stojanović, N. (2011). Nasledno pravo [Succession Law]. Niš, Pravni fakultet u Nišu, Centar za publikacije.

Šinkovec, J., \& Tratar, B. (2005). Veliki komentar Zakona o dedovanju s sodno prakso [The Big Commentary of Law of Succession Act with Judicial Practice]. Ljubljana.

Vaquer Aloy, A. (2011). Freedom of Testation, Compulsory Share and Disinheritance Based on Lack of Family Relationship. In Anderson, M., \& Arroyo i Amayuelas, E. (Eds.), The Law of Succession: Testamentary Freedom, European Perspectives (pp. 89-104). Europa Law Publishing.

Vujović, O. (2018). Svrha fideikomisa [The Purpose of Fideicommissum]. Godišnji zbornik radova, Pravni fakultet Univerziteta u Prištini sa privremenim sedištem u Kosovskoj Mitrovici [Annual Colletion of Papers, Faculty of Law, University of Priština temporarily settled in Kosovska Mitrovica]. Kosovska Mitrovica, 81-96. 


\title{
ДОКТРИНАРНО ОПРАВДАЊЕ ПОСТОЈАЫА УСТАНОВЕ НУЖНОГ ДЕЛА У САВРЕМЕНОЈ ЛЕГИСЛАТУРИ
}

\author{
Новак Крстић \\ Универзитет у Нишу, Правни факултет, Ниш, Република Србија
}

Резиме

Слобода завештања један је од темељних принципа наследног права, а установа нужног дела њено садржински најефикасније и најделотворније ограничење. У теорији наследног права све су снажнији позиви да се установа нужног дела укине, или бар модификује, а појединцу омогући шира слобода располагања својим имовинским правима. Стога је важно преиспитати основе на којима овај институт почива и размотрити да ли је његова егзистенција неопходна у савременом праву. Уколико јесте, којим аргументима се одржавање ове установе може оправдати.

У раду су најпре анализиране поставке класичних теорија којима се оправдава постојање установе нужног дела: теорије прећутног фидеикомиса, теорије породичне својине, теорије издржавања (алиментациона теорија), теорије породичне солидарности и теорије троструког правног основа, које разлог егзистенције установе нужног дела налазе у разноврсним правним и ванправним институтима и појмовима. Потом су изнета запажања о томе којим се аргументима данас може оправдати нормирање нужног наслеђивања у савременим правима.

У раду је изнет став да се основ једног правног института не мора увек налазити у правним појмовима, институтима, регулама. Бројне правне установе управо су и настале као израз филозофских погледа на одређене друштвене феномене и потребе за њиховим уобличавањем путем правних норми.

Постулати алиментационе теорије, која је заступљена међу бројним правним писцима и која основ нужног дела налази у потреби обезбеђења егзистенције најближим члановима породице из заоставштине оставиоца, могу бити полазна основа за објашњење постојања нужног дела, али она сама по себи никако није довољна да се оправда ова установа. Нужни део често не зависи од потреба нужних наследника, већ им се гарантује, без обзира на њихове имовинске прилике. И данас, када су споне међу члановима породице све слабије, када је отуђење несумњиво присутно, а осећај за припадност породици све слабији, и када су могућности за стицање зараде радно способних чланова породице веће, породична солидарност остаје вредност сама по себи. Стога, правила нужног наслеђивања треба да буду формулисана на бази породичне солидарности, са циљем егзистенцијалне заштите оставиоцу најближих лица - толико блиских да би било оправдано у интересу тих лица ограничити слободу оставиоца да својим добрима располаже како му је воља. У симбиози наведеног треба тражити ratio legis нужног дела. 